\title{
Meduloblastoma pediatrikoaren pronostikorako markatzaile molekularren identifikazioa
}

\author{
(Identification of molecular biomarkers for prognosis in pediatric \\ medulloblastoma)
}

\author{
Begoña Frutos-Gallastegui ${ }^{1}$, Elixabet López-López ${ }^{1,2}$, \\ Unai Illarregi ${ }^{1}$, Nerea Bilbao-Aldaiturriaga ${ }^{3}$, Miguel García-Ariza ${ }^{2,4}$, \\ Ángela Gutiérrez-Camino ${ }^{1,2}$, Idoia Martín-Guerrero ${ }^{* 1,2}$ \\ ${ }^{1}$ Genetika, Antropologia Fisikoa eta Animalien Fisiologia Saila (UPV/EHU) \\ ${ }^{2}$ Biocruces Bizkaia Osasun Ikerketako Institutua \\ ${ }^{3}$ iGin Institutua Bilbo \\ ${ }^{4}$ Onkologia pediatrikoa, Gurutzetako Unibertsitate ospitalea
}

\begin{abstract}
LABURPENA: Meduloblastoma klinika eta oinarri molekular heterogeneoa duen minbizia da. Azken urteotan, genoma osoko eta sekuentziazio masiboko teknika molekularren garapenaren ondorioz, meduloblastoma pediatrikoan parte hartzen duten mutazio asko identifikatzea ahalbidetu da. Hortaz, lanaren helburua izan zen meduloblastoma pediatrikoaren pronostikoan edota terapian lagundu dezakeen gene eta mutazio somatikoen panel baten diseinua egitea. Horretarako, meduloblastoma pediatrikoan eragina duten geneei buruzko informazioa duen literaturaren berrikuspen sistematikoa egin zen. Bilaketarako Pubmed datubase bibliografikoa erabili zen, honako termino hauek erabiliz: (Medulloblastoma*) AND («mutation*» OR «genetic alteration*» OR «genetic variation*»). Berrikuspen bibliografikoaren ondoren, hasieran zeuden 588 artikuluetatik 62 artikulutan 197 gene identifikatu ziren. Horietatik, \% 2 baino gehiagoko mutazio-maiztasuna zuten 21 gene aurkitu ziren, eta diagnosiaren momentuan balio pronostikoa edo meduloblastoma azpimoten ezaugarri ziren 5 gene (TP53, CTNNB1, PTCH1, SUFU eta KDM6A). Gene horiek analizatuz gero, profil molekularrean oinarritutako tratamendu indibidualizatuak doitu litezke.
\end{abstract}

HITZ GAKOAK: meduloblastoma, mutazio somatikoa, pronostikoa.

\begin{abstract}
Medulloblastoma is a very heterogeneous malignancy at both clinical and molecular levels. In recent years, thanks to the development of massive and whole genome sequencing techniques, many specific mutations have been discovered within each medulloblastoma subtype. Therefore, this study aimed to design a panel of somatic mutations and genes to allow the early recognition of poor prognosis patients or those that will develop resistance to therapy. With this aim, a systematic review was performed to identify all information available in the literature regarding mutations in genes involved in the development of pediatric medulloblastoma. We searched in PubMed database using the keywords and subject terms (Medulloblastoma $\left.^{*}\right)$ AND («mutation*» $O R$ «genetic alteration*» $O R$ «genetic variation*»). The original search provided 588 records, from which 62 were finally selected. Out of the 197 identified genes found in those records, 21 showed mutational frequencies higher than $2 \%$ and 5 (TP53, CTNNB1, PTCH1, SUFU and KDM6A) could be useful at diagnosis because of their prognostic value or because they were specific of a single subtype. The analysis of these genes could help achieve more individualized therapies based on molecular profile.
\end{abstract}

KEYWORDS: medulloblastoma, somatic mutation, prognosis.

* Harremanetan jartzeko / Corresponding author: Idoia Martín-Guerrero. Antropologia Fisikoa eta Animalien Fisiologia Saila, Zientzia eta Teknologia Fakultatea (UPV/EHU), Sarriena auzoa z/g, 48940, Leioa (Bizkaia). - idoia.martin@ehu.eus - https:// orcid.org/0000-0002-0098-1908

Nola aipatu / How to cite: Frutos-Gallastegui, Begoña; López-López, Elixabet; Illarregi, Unai; Bilbao-Aldaiturriaga, Nerea; García-Ariza, Miguel; Gutiérrez-Camino, Ángela; Martín-Guerrero, Idoia (2021). «Meduloblastoma pediatrikoaren pronostikorako markatzaile molekularraren identifikazioa». Ekaia, 40, 2021, 51-76. (https://doi.org/10.1387/ekaia.21686).

Jasotze-data: 2020, apirilak 27; Onartze-data: 2021, urtarrilak 2.

ISSN 0214-9753 - eISSN 2444-3581 / (c) 2021 UPV/EHU

(c) (i) $\odot$ Lan hau Creative Commons Aitortu-EzKomertziala-LanEratorririkGabe 4.0 Nazioartekoa lizentzia baten mende dago 


\section{SARRERA}

Meduloblastoma pediatrikoa nerbio-sistema zentraleko (NSZ) tumore primario ohikoena da; hain zuzen ere, NSZko tumore primario guztien $\%$ 15-20a da hori [1]. Garuneko tumore gaiztorik ohikoena da haurretan. Adina oso aldagai garrantzitsua da azpitaldeak ezartzeko. Kasu honetan, 3 urteko muga ezartzen da, alde batetik, adin honetan gaixotasunak jokaera biologiko agresiboagoa erakusten baitu, eta, horrez gain, erradioterapia ez emateko protokoloa baitago epe luzeko ondorio kaltegarriak ekiditeko. Ondorioz, baldintza horiek zuzen eragiten dute biziraupenemaitzetan. Espainian, azken hamarkadan, batez besteko intzidentziatasa urteko 30-40 kasukoa izan da. Hala ere, helduen nerbio-sistema zentraleko tumore primarioen $\% 3$ baino gutxiago izaten dira meduloblastomak [2].

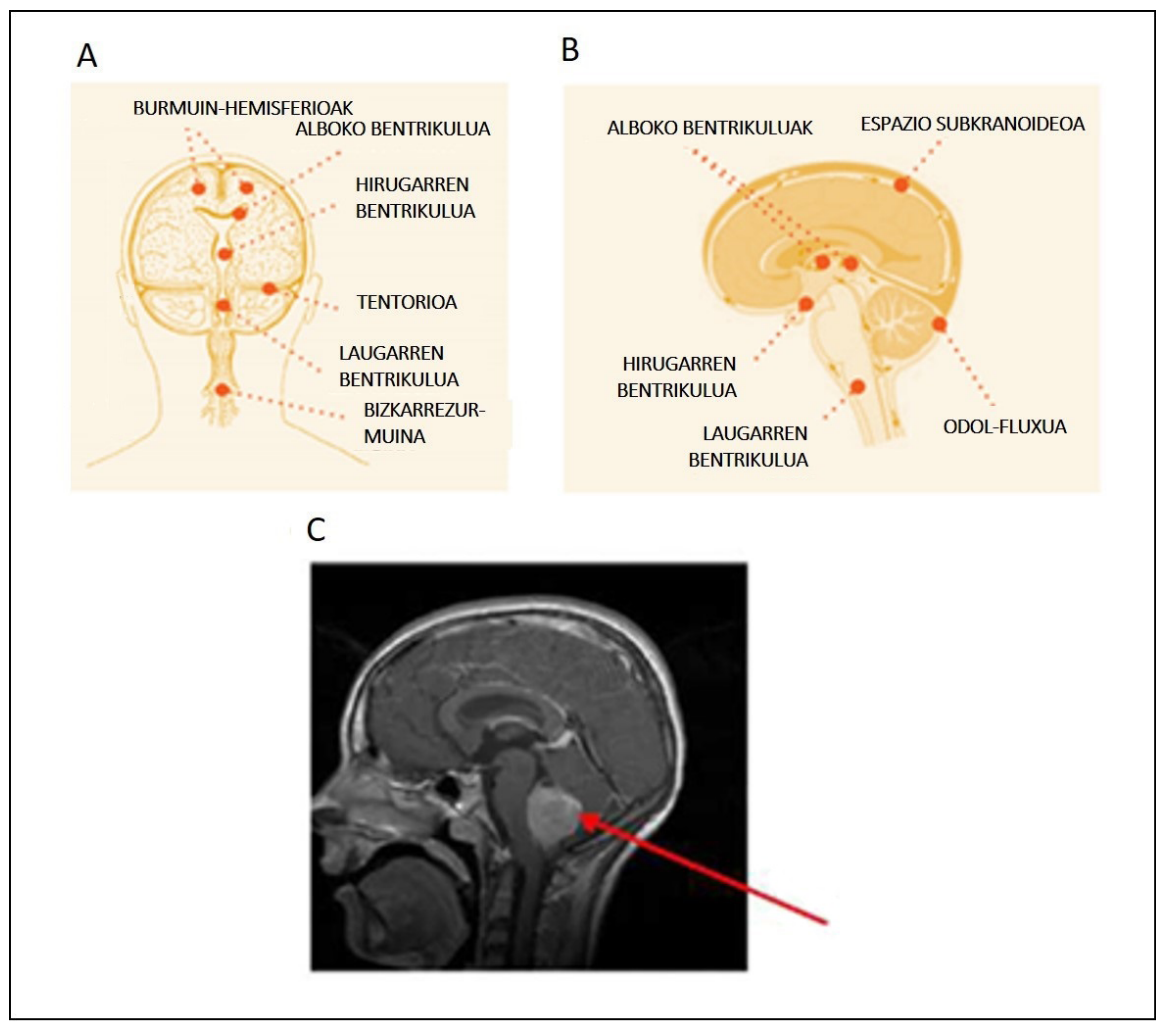

1. irudia. (A-B) Garunaren anatomia eta (C) meduloblastoma tumorearen kokapena (American Brain Tumor Association Web; http://www.abta.org/understanding-briantumors/anatomy/physical-structure.htlm) 
Meduloblastoma atzeko hobian dagoen tumore enbrionarioa da, normalean laugarren bentrikuluko sabaiko zerebelo-bermisetik sortzen dena (1. irudia). Tumore horrek likido zefalorrakideotik barreiatzeko joera dauka, eta diagnostikoan meduloblastoma kasuen \% 35ak metastasia aurkezten dute [3].

Orain arte, meduloblastomaren sailkapena histologian oinarritu da, eta lau mota bereizi dira: meduloblastoma klasikoa, desmoplasiko/nodularra, nodularitate zabalekoa, eta anaplasiko eta zelula handikoa. Azpitalde bakoitzak adierazpen kliniko ezberdina aurkezten du, pronostiko ezberdinei lotuta dagoena. Desmoplasikoek klasiko edo zelula handikoek baino biziraupen handiagoa dute adin-tarte berdinerako. Bestalde, zelula handiko meduloblastomek eta anaplasikoek hainbat ezaugarri partekatzen dituzte, eta agresibitate handiagoa erakusten dute. Hori dela eta, mota horiek pronostiko larriagoa dute [3].

Gaur egun, meduloblastoma tratatzeko, lehendabizi, erresekzio kirurgikoa egiten da. Jarraian, erradioterapia eta kimioterapia ematen dira. Tratamendua pazientearen arrisku-mailaren arabera ezartzen da, aldagai kliniko-patologikoak kontuan hartuz. Aldagai horiek dira adina, metastasiaren agerpena, erresekzioaren hedadura eta azpitalde histologikoa. Kasu batzuetan, kontuan hartzen dira $M Y C$ eta $M Y C N$ geneen anplifikazioak edo $\beta$-katenina kodetzen duen genearen mutazioak bezalako ezaugarri genetiko indibidualak ere. Aldagai eta ezaugarri horiekin bi arrisku-maila agertzen dira: arrisku estandarreko pazienteak ( $>3$ urteko adina, $M Y C / M Y C N$ negatiboak, histologia klasikoa, $<1,5 \mathrm{~cm}^{2}$-ko tumore hondarra, eta metastasirik ez izatea) eta arrisku handikoak (MYC/MYCN positiboak, histologia anaplasikoa, $>1,5 \mathrm{~cm}^{2}$-ko tumore hondarra edota diagnostikoaren momentuan metastasia izatea) bereizten dira [4]. Arriskuaren araberako tratamenduak biziraupen-tasa hobetu duen arren (Espainian \% 29ko igoera izan $\mathrm{du}$ [2]), sailkapen hori paziente kopuru esanguratsu batengan ez dela optimoa ondorioztatu da. Batzuek birgaixotze goiztiarrak izaten dituzte, nahiz eta arrisku baxuko kasu bezala sailkatuta egon; beste batzuek terapia intentsibo eta toxikoa jasotzen dute, hain intentsiboa ez den terapia batekin pronostiko ona eduki zezaketenean. Horrek esan nahi du gaur egun meduloblastoma sendaezina dela ia pazienteen herenarengan [5], eta arrisku estandarrean sailkatutako pazienteen \% 20-25engan. Gainera, aurrera egiten duten pazienteek epe luzera albo-ondorio toxikoak pairatzen dituzte, eta eragin nabarmenak izaten ditu gaixoen bizi-kalitatean[6-9]. Beraz, gaixotasun honen erronketako bat da birgaixotze-kasuak aurresatea, tratamendua doitu ahal izateko.

Azken urteotan, Next Generation Sequencing (NGS) delakoaren edo, euskaraz, Sekuentziazio Masiboko Teknika Molekularraren garapenaren ondorioz, meduloblastomaren biologia eta konplexutasuna hobeto ezagutzen da. Informazio horri esker, gaur egun badakigu meduloblastoma maila 
molekularrean gaixotasun heterogeneoa dela. Beraz, 2016ko Osasunaren Mundu Erakundearen (OME) sailkapenak [3], sailkapen histopatologikoaz gain, meduloblastomaren diagnosirako aldaera molekularrak sartu zituen: WNT aktibatua, SHH aktibatua (TP53 mutatua edo TP53 basatia), 3 taldea eta 4 taldea [10]. Talde bakoitzak DNA metilazio patroi espezifikoak, adierazpen genikoko profilak, aldaketa genomikoko patroiak eta iragarpen kliniko bereizgarriak ditu [4, 11-16].

WNT motako meduloblastoman WNT bidezidorraren aktibazioa gertatzen da. Askotan, mutazioak azaltzen dira 6. kromosomaren monosomian edota $C T N N B 1$ genearen 3. exonean. Normalean, sailkapen histologikoan klasikotzat hartzen dira, eta gutxitan eragiten dute metastasia. Batez ere, hiru urtetik gorako haurretan eta helduetan behatzen da, eta pronostiko onarekin erlazionatu ohi da [4].

Sonic hedgehog (SHH) motako meduloblastoma SHH bidezidorraren aktibazioarekin lotuta dago, eta, askotan, 9q kromosoman delezioak eta SHH bidezidorreko geneetan (PTCH1, PTCH2, SMO, SUFU eta GLI2) mutazioak aurkezten ditu. Histologikoki desmoplasiko/nodulartzat hartzen da. SHH tumore batzuek TP53 genean mutazioak izaten dituzte, eta hori, askotan, morfologia anaplasikoarekin dago lotuta. Pronostikoa adin-tartearen araberakoa da; haur txikietan, esate baterako, emaitza hobeak lortzen dira. Bestalde, TP53 genea mutatuta duten SHH meduloblastomek pronostiko larriagoa izaten dute [17-24].

3 taldeari dagokionez, sarritan $M Y C$ anplifikazioak izaten ditu. Azpitalde honetan kromosoma osoen edo kromosoma besoen DNA kopia-galerak edo -irabaziak dira garrantzitsuak $[25,26]$. Talde honetako meduloblastomak, sarritan, metastasikoak izaten dira, eta orokorrean pronostiko larriagoa erakusten dute beste azpitaldeekin alderatuz, $M Y C$ anplifikazioak dituztenek batez ere. Histologikoki, klasikoak zein zelula handikoak/anaplasikoak izan daitezke.

4 taldeko meduloblastomak klasikoak zein zelula handikoak/anaplasikoak izan daitezke. Sarrien agertzen den azpitaldea bada ere, bere ezaugarri biologikoak ezezagunak dira oraindik. Aberrazio ohikoena $17 \mathrm{q}$ isokromosoma da, eta $M Y C N$ anplifikazioak, SNCAIP bikoizketak eta $11 \mathrm{q}$ kromosomaren galerak ere agertzen dira, besteak beste. Batez ere, haur eta gazteengan agertzen da, eta gutxi gorabehera meduloblastomen \% 30a metastasikoa da diagnosian [11,27-29].

Minbizien genomak ikertzeko, NGS teknologiaren erabilerari esker, neoplasia ohikoenen mutazio somatikoen lehen katalogoa sortu da (International Cancer Genome Consortium, ICGC). Ikerketa horiek erakutsi dute mutazio batzuek hazkuntza-abantaila selektiboa sustatzen dutela, driver mutazioek alegia, eta beste batzuek ez, passenger mutazioek. Driver mutazioen aurkikuntzak gaixotasunaren oinarri molekularren ezagu- 
men handiagoa ahalbidetzen du, diagnostikoa eta tratamenduen aukeraketa erraztuz. Meduloblastoman, zehazki, azpitalde bakoitzerako espezifikoak diren mutazio berrien identifikazioan oinarritu dira NGS ikerketak. Izan ere, mutazioak aurkezten dituzten geneen analisiek meduloblastomen sailkapena hobetzea eta terapia berrien diseinua ahalbidetu dituzte [18]. Gainera, teknologia horrek tumorearen bilakaera klonala karakterizatzeko aukera ematen du, berebizikoa dena gaixotasunaren tratamenduan. Adibidez, azpiklon nagusiek tratamenduen erresistentzian eragiten duten mutazio somatikoak parteka ditzakete. Gutxiengoan dauden azpiklonaketa de novo mutazioek, aldiz, birgaixotzea edo aurrerago erresistentzia azaltzea eragin dezakete [19]. Mutazio horien NGS bidezko identifikazioa, bai jatorrizko tumorean, bai metastasian eta birgaixotzean, lagungarria izan daiteke tratamenduen erresistentzia eta birgaixotzeak ulertzeko. Aurkikuntza horiek etorkizun hurbilean terapia pertsonalizatuagoak diseinatzea ahalbidetuko dute.

Esan bezala, meduloblastoma minbizi heterogeneoa da, adierazpen klinikoa, ezaugarri molekularrak eta azpitalde bakoitzaren biziraupen-tasa kontuan hartzen baditugu. Pazientearen arrisku histopatologikoaren araberako tratamenduen estratifikazioak biziraupenean hobekuntza ekarri duen arren, sailkapen hori oraindik ez da nahikoa. Tratamendu gogorrenek biziraupenean hobekuntza ekarri dute, baina gaixotze-tasa altuaren truke. Gainera, ez da ahaztu behar gaur egun ez dagoela birgaixotzeko aurreikuspenaren adierazle den datu biologikorik. Hori guztiori kontuan hartuta, meduloblastoma-laginak molekularki karakterizatzeko beharra planteatzen da lan honetan, tumore horien biologian sakontzeko eta, horrela, diagnostikoaren unetik tratamendu-estrategia bideratuagoak garatzeko. Gainera, errutina klinikorako beharrezkoa da itu-geneen panel zuzendua (sinadura genetikoa), zeinak pronostiko edota terapiarako analisi azkar eta fidagarria ahalbidetu ahal izango baitu.

Gaur egun, meduloblastoman mutatutako geneen panelen diseinua posible da literaturan dagoen informazio guztiari esker. Ildo horretan, dagoeneko identifikatu dira meduloblastoma azpitalde ezberdinetan garrantzia duten mutazioak. Hala ere, beharrezkoa da informazioa gehitzea arlo honetan informazio garrantzitsua jaso dezaketen itu-geneak definitu ahal izateko. Horregatik, geneen eta horien mutazio somatikoen panela diseinatzeak duen garrantzia azpimarratu nahi dugu. Izan ere, gene horien NGS bidezko analisiak tratamendu eraginkorragoen garapena ahalbidetu dezake. Hori kontuan izanik, lan honen helburua da meduloblastoma pediatrikoaren pronostikoan edota terapian erabilgarria izan daitekeen gene eta mutazio somatikoen panela diseinatzea. Horretarako, meduloblastoma pediatrikoan eragina duten geneei buruzko informazioa duen literaturaren berrikuspen sistematikoa egin da. 


\section{MATERIALA ETA METODOAK}

Meduloblastoman mutazio somatikoak aztertzen dituzten artikuluak identifikatzeko bilaketa sistematikoa egin zen. Bilaketarako Pubmed datubase bibliografikoa erabili zen, honako termino hauekin: (Medulloblastoma*) AND («mutation*» OR «genetic alteration*» OR «genetic variation*»). Hitzgako ez-espezifikoak erabili genituen pronostikoari buruzko artikulu guztiak aurkitu ahal izateko. Bilaketan, 2020ko martxora arte argitaratuta zeuden erregistro guztiak hartu ziren kontuan. Termino horiekin, 588 artikulu agertu ziren.

Bi hautaketa fase gauzatu ziren. Lehenengo hautaketa fasea artikuluen laburpenen irakurketan oinarritu zen. Laburpenik ez zuten artikuluak zuzenean bigarren fasera pasatu ziren. Artikuluak hautatzeko, barneratze- eta baztertze-irizpide desberdinak erabili ziren (1. taula).

1.taula. Artikuluak hautatzeko erabilitako barneratze- eta baztertze-irizpideak.

\begin{tabular}{lc}
\hline \multicolumn{1}{c}{ Barneratze-irizpideak } & Baztertze-irizpideak \\
\hline - Meduloblastoma izatea. & - Ingelesa edo gaztelania ez den beste hizkuntza \\
- Mutazio somatikoak aurkez- & batean argitaratuta egotea. \\
tea. & - Beste argitalpen mota bat izatea: berrikuspenak, \\
- Pazienteak 18 urtekoak edo & editoreari igorritako gutunak, iruzkinak, etab. \\
gazteagoak izatea. & - Gizakia ez den beste organismo edo lerro zelula- \\
& rretan egindako lanak izatea. \\
& - Aldaera genetikorik ez aztertzea: DNA metila- \\
& zioa, adierazpena edo bestelakoak. \\
& Polimorfismoak aztertzea. \\
& - Translokazioak eta inbertsioak (aldaera genetiko \\
& luzeak) aztertzea. \\
& - Ikerketa funtzionalak izatea. \\
\hline
\end{tabular}

Artikuluen laburpenen irakurketaren ondoren, lehengo fasean 402 artikulu baztertu ziren. Bigarren fasean, 186 artikuluak osorik irakurri ziren. Baztertze-irizpideak aurreko berdinak izan ziren, baina, horiez gain, hauek ere gehitu ziren: mutazioei buruzko informaziorik ez adieraztea, gaixoen adina ez adieraztea, aztertutako meduloblastoma-kasuen kopurua ez adieraztea, eta artikulua eskuragarri ez egotea. Prozesu hori egin ondoren, barneratze-irizpide horiek betetzen zituzten 62 artikulu hautatu ziren (2. irudia).

Barneratze-irizpideak betetzen zituzten artikuluetatik, honako informazio hau bildu zen: argitalpen-urtea, paziente kopurua, meduloblastoma azpitaldea (molekularra edota histologikoa), aztertutako geneak, aurkitutako mutazio somatikoak, mutazioak zituzten pazienteen maiztasuna, sekuentziazio-metodoa eta pronostikoa. 


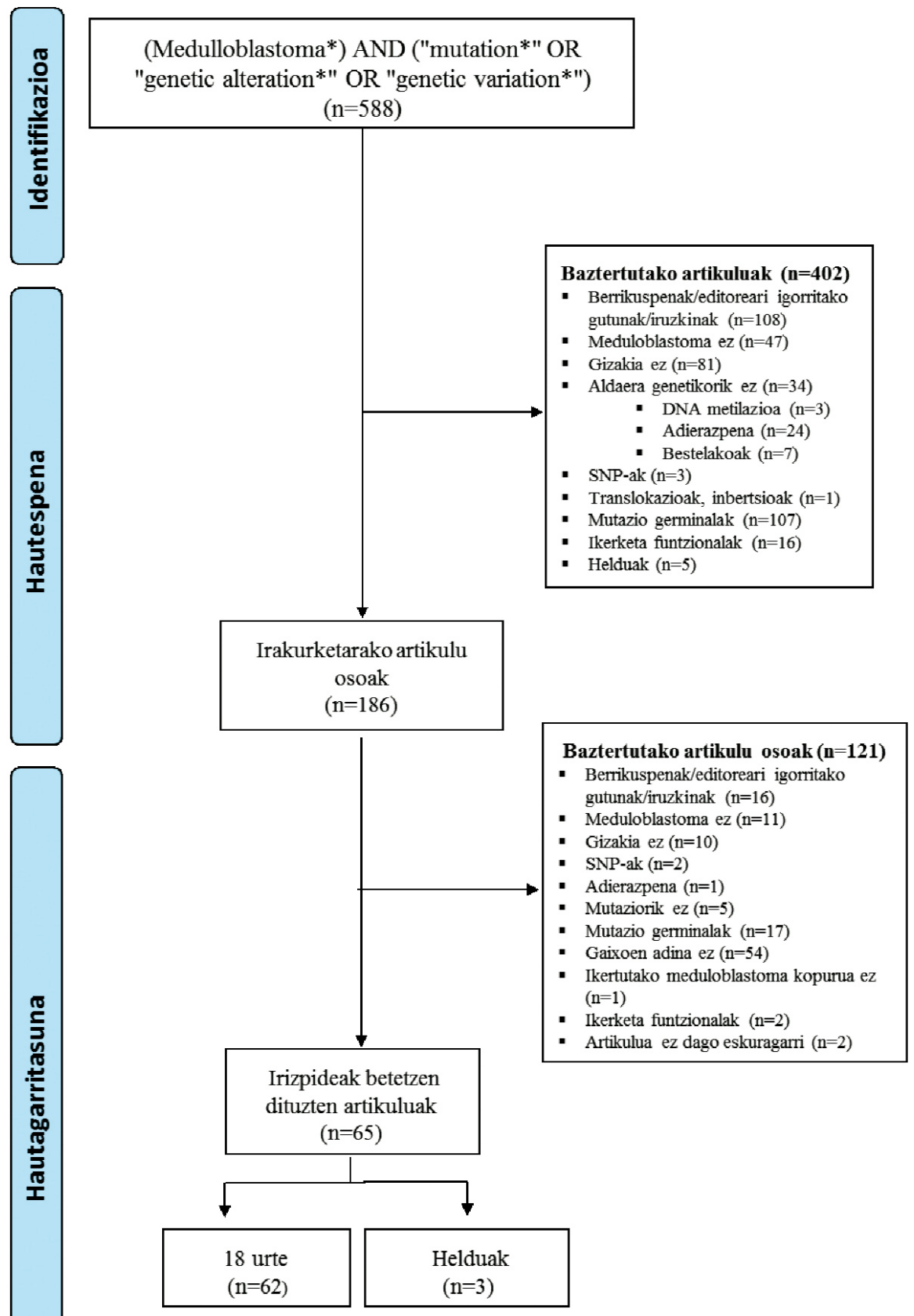

2. irudia. Onartutako eta baztertutako artikuluen flow-charta. 
Erabilitako artikuluen kalitatea bi ikertzaile independentek aztertu zuten (laginaren tamaina, sekuentziazio-teknika, lortutako emaitzak). Artikuluak honako kalifikazio hauekin ebaluatu ziren (Oxford Zentroak Medikuntzarako Ebidentzian oinarritutako ikerketa indibidualen kalitatekalifikazioetatik aldatuta): 1, kalitatezko entsegu kliniko aleatorioa, berrikuspen sistematikoa eta metanalisia; 2, ondo diseinatutako eta kontrolatutako ausazkotasunik gabeko saiakuntza, konparaziozko eta etorkizunezko kohortearen saiakuntza; 3, kasu-kontrol ikerketak, kohorte-ikerketa erretrospektiboa; 4, esku-hartzearekin edo esku-hartzerik gabe diren kasuetako serieak, zeharkako ikerketak; 5 , errespetatutako autoritateen iritzia eta kasutxostenak. Zalantzak bi ikertzaileren artean argitu ziren, artikuluen irakurketa zehatz baten bidez.

\section{EMAITZAK}

Meduloblastoma pediatrikoaren bilaketa sistematikoa egin ondoren, guztira 197 genetan aztertu ziren mutazio somatikoak. Horietatik guztietatik 21 genetan topatu ziren mutazio-maiztasuna \% 2koa baino handiagoa duten mutazioak aztertu genituen.

Mutazio somatikoak aztertzen zituzten 62 artikuluetatik 40k sailkapen histologikoan edo sailkapen molekularrean oinarrituta aztertu zituzten meduloblastomak. Beste 22ek, aldiz, meduloblastoma guztiak batera aztertu zituzten inolako sailkapenik egin gabe (2. taula). Sailkapenik egin ez zuten eta sailkapen histologikoa egin zuten artikuluak ziren zaharrenak. Sailkapen molekularrean oinarritu ziren artikuluak, aldiz, 2012-2019 urtekoak ziren.

2. taula. Mutazio somatikoak aztertu zituzten artikuluen sailkapena.

\begin{tabular}{l|c|c|c|c}
\hline & Artikulua & Sekuentziazio-metodoa & $\begin{array}{c}\text { Aztertutako gene } \\
\text { kopurua }\end{array}$ & Urtea \\
\hline Sailkapenik ez & {$[30-48]$} & $\begin{array}{c}\text { NGS,WES, Sanger } \\
\text { sequencing eta } P C R / \\
\text { SSCP analysis }\end{array}$ & $1-50$ & $1991-2017$ \\
\hline $\begin{array}{l}\text { Sailkapen } \\
\text { histologikoa }\end{array}$ & {$[49-63]$} & $\begin{array}{c}\text { Target DNA sequencing, } \\
\text { NGS, Sanger sequencing } \\
\text { eta } \text { PCR/SSCP analysis }\end{array}$ & $1-112$ & $1991-2017$ \\
\hline $\begin{array}{l}\text { Sailkapen } \\
\text { molekularra }\end{array}$ & {$[64-76]$} & $\begin{array}{c}\text { Target DNA sequencing, } \\
\text { NGS, WES eta Sanger } \\
\text { sequencing }\end{array}$ & $1-$ WES & $2012-2019$ \\
\hline
\end{tabular}

Laburdurak: NGS: Next Generation Sequencing; PCR: Polimerase Chain Reaction; SSCP: Single-Strand Conformation Polymorphism; WES: Whole Exome Sequencing. 
Mutazioak aztertzeko erabilitako sekuentziazio-metodoak ere desberdinak izan ziren ikerketaren arabera. Ondorioz, ikerketa bakoitzean aztertu zen gene kopurua ere ezberdina izan zen: batzuetan, gene bakarra aztertu zuten; beste batzuetan, aldiz, Whole Exome Sequencing (WES) edo NGS sekuentziazio-metodoen bidez genoma osoak sekuentziatu ziren gene desberdinak aztertuz.

\subsection{Sailkapenik ez duten meduloblastomak}

Sailkapenik egin ez zuten ikerketetan, mutazio somatikoen maiztasun handiena erakutsi zuten geneak honako hauek izan ziren: CTNNB1, TP53, PTCH1, TERT, AXIN1, FAT1, INI1, KDM6A eta APC (3. taula). TP53 geneak erakutsi zuen mutazio-maiztasunik handiena. Gene horretan aurkitutako mutazio somatikoen maiztasuna oso aldakorra izan zen. Izan ere, zenbait kasutan ez zen mutaziorik aurkitu; beste batzuetan, aldiz, aztertutako meduloblastomen $\%$ 20k aurkeztu zuten mutazioa TP53 genean. CTNNB1 genean, mutazioak aurkeztu zituzten meduloblastomak \% 6,940,5 izan ziren, eta $\mathrm{NII}$ genearen kasuan, \% 4,3-13,8. PTCHI genea pazienteen $\% 12$,1 ean ageri zen mutatuta, TERT genea \% 50ean, AXINI genea \% 2,6an, $F A T 1$ genea \% 30,4an eta $A P C$ genea \% 4,3an. KDM6A genea kasuen \% 20-100ean agertu zen mutatuta. Hala ere, \% 100eko maiztasuna azaldu zuen artikuluan, paziente bakarra aztertu zen.

Gene bakoitzean agertu ziren mutazioak desberdinak izan ziren, baina gehienetan aminoazido-aldaketa bat dakarten mutazio ez-sinonimoak ziren (3. taula). Pronostikoari dagokionez, TP53 eta CTNNB1 geneetan bakarrik azaltzen zen, eta, beraz, ez dago beste geneetako pronostikoaren informaziorik. TP53ren kasuan, mutazioak aurkezten zituzten pazienteek pronostiko larria zuten. $C T N N B 1$ genearen kasuan, aldiz, pronostiko ona zuten.

\subsection{Sailkapen histologikoa duten meduloblastomak}

Sailkapen histologikoan oinarrituta, mutazioak aztertu zituzten artikuluetan gene garrantzitsuenak TP53, CTNNB1, PTCH1, TERT, SMARCA4, $S U F U$ eta $M L L 2$ izan ziren (4. taula). Horiez gain, beste gene batzuek ere mutazioak aurkeztu zituzten, gutxienez \% 2ko maiztasunean: AXINl, $M L L 3, N R A S, K D M 6 A$ eta PTEN. Beste hiru gene ere mutatuta azaldu ziren, $A P C, N F 2$ eta $M S H 6$. Bai gene horien bai PTCH1 eta $S U F U$ geneen kasuetan, meduloblastoma zelula handikoa/anaplasikoa diagnostikatu zitzaion paziente bakarrari egin zitzaion analisi genetikoa.

Gene gehienak meduloblastoma klasikoetan ageri ziren mutatuta, KDM6A eta PTEN izan ezik. Horiek meduloblastoma desmoplasiko/nodularrean bakarrik azaldu ziren mutatuta \% 12,5eko maiztasunean. Meduloblastoma desmoplasiko/nodularrean $S U F U$ ere azaldu zen muta- 
tuta kasuen \% 4,4an. Meduloblastoma klasikoan soilik AXIN1, MLL3 eta NRAS geneek azaldu zituzten mutazioak, eta haien maiztasunak \% 5 , $\%$ 4,8 eta \% 6,3 izan ziren, hurrenez hurren. Azkenik, SMARCA4 genean ere mutazioak meduloblastoma klasikoetan baino ez ziren aurkitu, $\%$ 13,3ko maiztasunean.

3. taula. Meduloblastoman sailkapenik egin ez duten artikuluetan mutazio somatiko ugari erakutsi dituzten geneak, mutazioen maiztasunak eta pronostikoa.

\begin{tabular}{|c|c|c|c|c|}
\hline Genea & Mutazioa & Maiztasuna & Pronostikoa & Artikulua \\
\hline$C T N N B 1$ & $\begin{array}{l}\text { D32Y*; D32N*; D32V*; } \\
\text { S33Y*; S33C*; S33F*; } \\
\text { G34E*; S37Y; S37C }\end{array}$ & $\% 6,9-40,5$ & Ona [36] & $\begin{array}{c}{[35] ;[36] ;} \\
{[40]}\end{array}$ \\
\hline TP53 & $\begin{array}{l}\text { c.124del.; K132R; R175H; } \\
\text { S215N; C242Y; R248Q; } \\
\text { R273C; D281H; R282W }\end{array}$ & $\% 0-20$ & Larria [34] & $\begin{array}{c}{[30] ;[34] ;[38] ;} \\
{[43-47]}\end{array}$ \\
\hline PTCHI & $\begin{array}{c}\text { 3470delCG>fs; } \\
\text { 153IVS10+1G>A; c. } \\
\text { G3417A; c.G3490A }\end{array}$ & $\% 12,1$ & Ezezaguna & [42] \\
\hline TERT & c.C228T; с.C250T & $\% 50$ & Ezezaguna & {$[33]$} \\
\hline$A X I N 1$ & P255S; S263C & $\% 2,6$ & Ezezaguna & {$[37]$} \\
\hline FAT1 & $\begin{array}{c}\text { L123F; P882S; E1141D; } \\
\text { G1961S; I3726N; T3940T; } \\
\text { D4331H }\end{array}$ & $\% 30,4$ & Ezezaguna & [31] \\
\hline INII & $\begin{array}{c}\text { c.C472T }(\mathrm{R}>\mathrm{X}) ; \text { c.X141A } \\
(\mathrm{Y}>\mathrm{X}) ; \text { c.A379G }(\mathrm{R}>\mathrm{G}) \\
\text { c.545delA; c.G153A }(\mathrm{W}>\mathrm{X})\end{array}$ & $\% 4,3-13,8$ & Ezezaguna & [39];[41] \\
\hline KDM6A & Q1385X & $\% 20-100$ & Ezezaguna & {$[32] ;[48]$} \\
\hline$A P C$ & $\begin{array}{c}\text { c.C1296T; c.G1472A; } \\
\text { c.A1495G }\end{array}$ & $\% 4,3$ & Ezezaguna & [41] \\
\hline
\end{tabular}

* Mutazio hauek paziente batean baino gehiagotan aurkitu ziren. Mutazioetan aminoazidoen aldaketa adierazi ez bada, baseen aldaketa adierazi da.

Beste gene batzuek, meduloblastoma klasikoetan mutazioak aurkezteaz gain, beste azpitalde batzuetan ere aurkeztu zituzten mutazioak. Esate baterako, CTNNB1 geneak zelula handiko meduloblastoman edo meduloblastoma anaplasikoan ere mutazioak aurkeztu arren $(\% 1,03)$, ugariagoak izan ziren meduloblastoma klasikoetan (\% 0-15,8). TP53 genearen kasuan, 
meduloblastoma klasikoan ugariak izan ziren mutazioak (\% 41,6), baina meduloblastoma desmoplasiko/nodularrean ere mutazioak azaldu ziren $(\% 4,9)$.

Zenbait gene azpitalde klasikoan mutatuta azaldu arren, mutazioak ugariagoak izan ziren beste azpitalde batzuetan. PTCH1 eta TERT geneetan, adibidez, mutazioak ugariagoak izan ziren meduloblastoma desmoplasiko/nodularretan. $\mathrm{PTCH1}$ genean, meduloblastoma klasikoetan \% 7,17,3koaizanzenmutazio-maiztasuna;desmoplasiko/nodularretan,aldiz, \% 4,89koa. TERT genean, meduloblastoma klasikoetan \% 2,7koa izan zen mutazioen maiztasuna, eta desmoplasiko/nodularretan, aldiz, \% 8,1ekoa. MLL2 genean, meduloblastoma klasikoetan mutazioak aurkezteaz gain, meduloblastoma anaplasikoetan ere ageri ziren. Gainera, azken horretan mutazioen maiztasuna handiagoa izan zen: klasikoan \% 4,8-6,6koa, eta anaplasikoan \% 2,4-13,3koa.

4. taula. Sailkapen histologikoan oinarrituta mutazioen maiztasun esangarria erakutsi duten geneak, eta horietan ageri diren mutazioak eta pronostikoa.

\begin{tabular}{|c|c|c|c|c|c|}
\hline Azpitaldea & Genea & Mutazioa & Maiztasuna & Pronostikoa & Artikulua \\
\hline \multirow{9}{*}{ Klasikoa } & TP53 & $\begin{array}{c}\text { R174S; G244D; R248W; IVS6 } \\
+ \text { +2G }>\text { A; F270S }\end{array}$ & $\% 41,6$ & Ezezaguna* & [55] \\
\hline & $C T N N B 1$ & 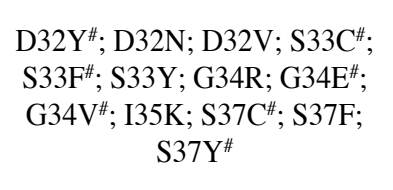 & $\% 0-15,8$ & $\begin{array}{c}\text { Ona [52]; [53]; } \\
\text { [56] } \\
\text { Biziraupenean } \\
\text { desberdintasu- } \\
\text { nik ez [61] }\end{array}$ & $\begin{array}{c}{[51-54]} \\
{[56-58]} \\
{[60]}\end{array}$ \\
\hline & PTCHI & $\begin{array}{c}\text { W926C; V11641I; } \\
\text { c.1862_1863delG> fs; } \\
\text { IVS14+1delG; c.3155_3158- } \\
\text { dupCGGC>fs; c.1738_1739in } \\
\text { sAGTGGTGTTCAATTTTGC } \\
\text { CACTGGTTCTGCTCATT>f } \\
\text { s; G2503T }\end{array}$ & $\% 7,1-7,3$ & Ezezaguna* & [51]; [62] \\
\hline & SMARCA4 & T910M; R1157W & $\% 13,3$ & Ezezaguna* & {$[51]$} \\
\hline & $M L L 2$ & $\begin{array}{c}\text { R485Q; c.3880_3883delGACT } \\
\text { > fs; G4601E }\end{array}$ & $\% 4,8-6,6$ & Ezezaguna* & [51] \\
\hline & TERT & c. $124 \mathrm{GA}$ & $\% 2,7$ & Ezezaguna* & [50] \\
\hline & MLL3 & - & $\% 4,8$ & Ezezaguna* & [51] \\
\hline & AXIN1 & - & $\% 5$ & Ezezaguna* & [58] \\
\hline & $N R A S$ & - & $\% 6,3$ & Ezezaguna* & {$[63]$} \\
\hline
\end{tabular}


Begoña Frutos-Gallastegui, Elixabet López-López, Unai Illarregi,

Nerea Bilbao-Aldaiturriaga, Miguel García-Ariza,

Ángela Gutiérrez-Camino, Idoia Martín-Guerrero

\begin{tabular}{|c|c|c|c|c|c|}
\hline Azpitaldea & Genea & Mutazioa & Maiztasuna & Pronostikoa & Artikulua \\
\hline \multirow{6}{*}{$\begin{array}{l}\text { Desmoplasiko/ } \\
\text { nodularra }\end{array}$} & TP53 & R175H; IVS3-2T>C; & $\% 4,9$ & Ezezaguna* & [51] \\
\hline & PTCH1 & $\begin{array}{c}\text { G1093X; c.563delT>fs; } 1576- \\
\text { del2 >fs; } 3112 \text { ins } 28>\text { fs; } \\
\text { 2784ins7>fs; TC1869A }\end{array}$ & $\% 4,8-9$ & 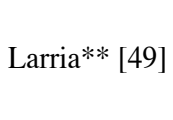 & $\begin{array}{l}{[49] ;[51] ;} \\
{[61] ;[62]}\end{array}$ \\
\hline & TERT & c. 124 AA (2); c. 124 GA & $\% 8,1$ & Ezezaguna* & {$[50]$} \\
\hline & $S U F U$ & $\begin{array}{c}\text { IVS8: G>A; 1129- } \\
\text { delTCCGGAG }\end{array}$ & $\% 4,4$ & Ezezaguna* & [59] \\
\hline & KDM6A & - & $\% 12,5$ & Ezezaguna* & [49] \\
\hline & PTEN & - & $\% 12,5$ & Ezezaguna* & [49] \\
\hline \multirow{7}{*}{$\begin{array}{l}\text { Zelula } \\
\text { handikoa/ } \\
\text { anaplasikoa }\end{array}$} & $M L L 2$ & $\begin{array}{c}\text { 47718725delC }>\mathrm{fs} ; \\
\text { 47712043C }>\mathrm{T} ; \\
\text { c.5198_5199insCATCCAC }>\mathrm{fs}\end{array}$ & $\% 2,4-13,3$ & Ezezaguna* & [51] \\
\hline & CTNNB1 & D32V; S33C & $\% 1,03$ & Ona [52] & [52] \\
\hline & $A P C$ & c. $38833 \mathrm{C}>\mathrm{A}$ & $\% 100 * * *$ & Ezezaguna* & {$[63]$} \\
\hline & $N F 2$ & c. $1248 \mathrm{G}>\mathrm{T}$ & $\% 100 * * *$ & Ezezaguna* & {$[63]$} \\
\hline & PTCH1 & c. $634 \mathrm{G}>\mathrm{T}$ & $\% 100 * * *$ & Ezezaguna* & [63] \\
\hline & SUFU & c. $1365+1 \mathrm{G}>\mathrm{T}$ & $\% 100 * * *$ & Ezezaguna* & {$[63]$} \\
\hline & MSH6 & c. $2722 \mathrm{G}>\mathrm{T}$ & $\% 100 * * *$ & Ezezaguna* & {$[63]$} \\
\hline
\end{tabular}

* Pronostikoa ez da aztertu, edo ezezaguna da; **tratamenduan eragiten du; ***paziente bakarra aztertu da; " mutazio hauek gutxienez paziente batengan baino gehiagorengan aurkitu ziren. Oharra: mutazioetan aminoazidoen aldaketa adierazi ez bada, baseen aldaketa adierazi da.

Geneetan aurkitu diren mutazioei erreparatuz, oro har, aminoazidoen aldaketak eragiten dituzten baseen aldaketak ziren. Baina, zenbait genetan, delezioak edo insertzioak azaldu ziren. Horien ondorioz, zenbait kasutan proteinaren irakurtarauaren aldaketa gertatzen da. Mutazio mota horiek, batez ere, $P T C H 1$ eta $M L L 2$ geneetan ageri ziren.

Pronostikoari dagokionez, gene gehienetarako ezezaguna zen edo ez zuten aztertu. Hala ere, zenbait genetan ezaguna zen pronostikoa. Adibidez, CTNNB1 genean mutazio horien pronostikoa ona zela adierazi zuten hiru ikerketa-lanek - [52], [53], [56]—, eta beste lan batek biziraupenean desberdintasunik ez zegoela adierazi zuen [61]. Pronostikoa ona zen bai meduloblastoma klasikoetan bai anaplasikoetan gene horretarako. Aldiz, PTCHI geneak meduloblastoma desmoplasiko/nodularrerako pronostiko larria zuen, eta horrek eragina zuen tratamenduan [49]. 


\subsection{Sailkapen molekularra duten meduloblastomak}

Meduloblastomak molekularki sailkatu zituzten ikerketetan, gutxienez \% 2ko maiztasuna azaldu zuten mutazio somatikodun geneak TP53, CTNNB1, PTCH1, TERT, DDX3X, SMARCA4, MLL2, SUFU, KMT2D, PTEN, PIK3A, SMO, CHD7 eta KDM6A geneak izan ziren (5. taula). Orokorrean, mutazio somatikoak dituzten zenbait gene azpitalde molekular batekin daude erlazionatuta. Hala ere, zenbait kasutan, mutazio somatikoak dituzten geneak azpitalde molekular gehiagotan agertu ziren.

WNT azpitaldean, $K M T 2 D$ eta $S M O$ geneek soilik azaldu zituzten mutazioak. Pazienteen \% 20,5ek eta \% 0-3,8k zituzten gene horiek mutatuta. CTNNB1 genea batez ere WNT azpitaldean azaldu zen mutatuta maiztasuntarte nahiko zabalarekin (\% 5,9-100), baina 3 taldean ere mutazioak azaldu ziren gene honetan. Dena den, kasu horretan maiztasun oso baxuarekin, $\%$ 1,3koarekin, hain zuzen. SMARCA4 genearen kasuan, WNT, SHH eta 3 taldea azpitaldeetan azaldu zituzten mutazioak. Hala ere, CTNNB1 genean bezala, genea mutatuta zeukaten pazienteen maiztasuna handiagoa izan zen WNT azpitaldean, maiztasunak \% 2,6-25,6, \% 1,26-6,0 eta \% 2,65ekoak izanik WNT, SHH eta 3 taldean, hurrenez hurren. $D D X 3 X$ genearen kasuan ere, mutazioak aurkeztu zituzten pazienteak azpitalde desberdinetan sailkatuta zeuden, maiztasunak desberdinak izanik azpitalde bakoitzerako: WNT azpitaldean \% 3,6-32, SHH azpitaldean \% 1,7-2,5 eta 3 taldean $\%$ 1,2. MLL2 geneak orokorrean ez zituen mutazioak azaldu maiztasun altuan. Baina WNT azpitaldean maiztasuna \% 2,6koa zen, eta SHH azpitaldean \% 1,4koa; WNT azpitaldean altuagoa, hortaz.

TP53 genea WNT, SHH eta 4 taldea azpitaldeetan azaldu zen mutatuta, maiztasuna WNT azpitaldean \% 2,4-15ekoa izanik.

SHH azpitaldeari dagokionez, zenbait genek aurkeztu zuten paziente mutatuen maiztasunik handiena: PTEN, SUFU, PIK3A eta TERT geneek. Gene horiek mutatuta zituzten pazienteen maiztasunak \% 2,4-5,3, \% 1,3$3,6, \% 10,5$ eta $\% 4-50$ izan ziren, hurrenez hurren.

PTCH1 genean mutazio somatikoak ageri ziren bai WNT azpitaldean bai SHH azpitaldean. Mutazioen maiztasunari erreparatuz, PTCH1 genearen kasuan, oso aldakorra izan zen SHH azpitaldean, \% 1,7-100ekoa, hain zuzen. WNT azpitaldean, aldiz, maiztasuna \% 3,8koa izan zen. Azpimarragarria da taula honetan azaltzen den maiztasunak hein oso zabala adierazten duela. Tarte zabal hori SHH azpitaldean terapiaren erantzuna aztertzen duen artikuluko datuei dagokio [65], eta taula honetan medublastomak azpitaldean sailkatu genituen. Beraz, ehunekoa edo hein orokorra aztertu nahi izanez gero, 5 . taula behatu beharko genuke.

3 taldean beste azpitaldeetan mutatuta azaldu ziren geneek azaldu zituzten mutazioak. Azpimarratzekoa da 3 taldean mutazioen maiztasuna ba- 
Begoña Frutos-Gallastegui, Elixabet López-López, Unai Illarregi,

Nerea Bilbao-Aldaiturriaga, Miguel García-Ariza,

Ángela Gutiérrez-Camino, Idoia Martín-Guerrero

xuagoa zela beste azpitaldeetan baino, eta $C H D 7$ genea ere azaldu zela mutatuta \% 2koa baino maiztasun txikiagoarekin bazen ere.

5. taula. Sailkapen histologikoan oinarrituta mutazioen maiztasun esangarria erakutsi duten geneak, horietan ageri diren mutazioak eta horien pronostikoa.

\begin{tabular}{|c|c|c|c|c|c|}
\hline Azpitaldea & Genea & Mutazioa & Maiztasuna & Pronostikoa & Artikulua \\
\hline \multirow{8}{*}{ WNT } & TP53 & $\mathrm{R} 267 \mathrm{~W} ; \mathrm{R} 282 \mathrm{~W}$ & $\% 2,4-15$ & Ezezaguna* & [64]; [66]; [71] \\
\hline & CTNNB1 & $\begin{array}{l}\text { D32A; D32Y\#; S33C } \\
\text { S33F\#; G34R; S37Y; } \\
\text { D32N }\end{array}$ & $\%$ 5,9-100 & Ona [64]; [66] & $\begin{array}{l}{[64] ;[66-68]} \\
{[71] ;[73] ;[74]}\end{array}$ \\
\hline & PTCH1 & - & $\% 3,8$ & Ezezaguna* & [64] \\
\hline & $D D X 3 X$ & $\begin{array}{l}\text { I214S; R326C; D329V; } \\
\text { R351W; F357S; R376S; } \\
\text { M380I; S412F; R475C; } \\
\text { H527Y; G530A; R534S }\end{array}$ & $\% 3,6-32$ & Ezezaguna* & [64]; [70-72] \\
\hline & SMARCA4 & $\begin{array}{l}\text { T910M; G1232S; } \\
\text { R1491X }\end{array}$ & $\% 2,6-25,6$ & Ezezaguna* & [64]; [70] \\
\hline & $M L L 2$ & E839X; C1523F; R5048H & $\% 2,6$ & Ezezaguna* & [73] \\
\hline & $K M T 2 D$ & - & $\% 20,5$ & Ezezaguna* & [64] \\
\hline & $S M O$ & - & $\% 0-3,8$ & Ezezaguna* & [64]; [71];[73] \\
\hline \multirow{9}{*}{ SHH } & TP53 & $\begin{array}{l}\text { Y205S; V272M; R175H; } \\
\text { R248W }\end{array}$ & $\% 2,6-33$ & Larria [66] & $\begin{array}{c}{[66-68] ;[70] ;} \\
{[72] ;[76]}\end{array}$ \\
\hline & PTCH1 & $\begin{array}{c}\text { L79fs; Y93X; Y191fs; } \\
\text { C226fs; E374X; H408N; } \\
\text { L447fs; 450_451del; } \\
\text { L450fs; S494fs; H671fs; } \\
\text { L818fs }\end{array}$ & $\%$ 3,8-100 & $\begin{array}{l}\text { Larria** [67] } \\
\text { SMO inhibitzai- } \\
\quad \text { lea [68] }\end{array}$ & $\begin{array}{c}{[67] ;[65] ;} \\
{[68] ;[70-73]}\end{array}$ \\
\hline & TERT & C228T; C228A; C250T" & $\% 4-50$ & Ezezaguna* & {$[66] ;[69] ;[75]$} \\
\hline & $D D X 3 X$ & R326C; R351W; M380I & $\% 1,7-2,5$ & Ezezaguna* & {$[68] ;[70] ;[72]$} \\
\hline & SMARCA4 & - & $\% 1,3-6,0$ & Ezezaguna* & [72] \\
\hline & $M L L 2$ & - & $\% 1,4$ & Ezezaguna* & [68] \\
\hline & $S U F U$ & $\begin{array}{l}\text { IVS8; C1084T; 1129- } \\
\text { delTCCGGAG; R362C }\end{array}$ & $\% 1,3-3,6$ & $\begin{array}{c}\text { Tratamenduarekiko } \\
\text { erresistentea [68] }\end{array}$ & [68]; [71-73] \\
\hline & PIK3A & - & $\% 10,5$ & Ezezaguna* & [67] \\
\hline & PTEN & - & $\% 2,5-5,3$ & Ezezaguna* & [67]; [71] \\
\hline
\end{tabular}


Meduloblastoma pediatrikoaren pronostikorako markatzaile molekularren identifikazioa

\begin{tabular}{c|c|c|c|c|c}
\hline Azpitaldea & Genea & Mutazioa & Maiztasuna & Pronostikoa & Artikulua \\
\hline \multirow{5}{*}{3} & $D D X 3 X$ & - & $\% 1,2$ & Ezezaguna* & {$[71]$} \\
\cline { 2 - 6 } & SMARCA4 & R1135W; T912K;E821K & $\% 2,6-5$ & Ezezaguna* $^{*}$ & {$[70] ;[71]$} \\
\cline { 2 - 6 } & $C T N N B 1$ & - & $\% 1,3$ & Ezezaguna* $^{*}$ & {$[72]$} \\
\cline { 2 - 6 } & $C H D 7$ & - & $\% 1,3$ & Ezezaguna* & {$[72]$} \\
\cline { 2 - 6 } & $T E R T$ & $\mathrm{C} 250 \mathrm{~T}$ & $\% 16,6$ & Ezezaguna* & {$[75]$} \\
\hline \multirow{4}{*}{$\mathbf{4}$ taldea } & $C H D 7$ & - & $\% 3,8$ & Ezezaguna* & {$[72]$} \\
\cline { 2 - 6 } & $T P 53$ & - & $\% 3,53$ & Ezezaguna* & {$[72]$} \\
\cline { 2 - 6 } & KDM6A & - & Ezezaguna* & {$[71]$} \\
\hline
\end{tabular}

* Pronostikoa ez da aztertu edo ezezaguna da; **tratamenduan eragiten du; ${ }^{*}$ mutazio hauek gutxienez paziente batengan baino gehiagorengan aurkitu ziren. Oharra: mutazioetan aminoazidoen aldaketa adierazi ez bada, baseen aldaketa adierazi da.

4 taldean, TP53 geneaz gain, $C H D 7$ eta KDM6A geneek ere azaldu zituzten mutazioak gutxienez \% 2ko maiztasunarekin. Bestalde, KDM6A genea ez zen mutatuta azaldu beste azpitaldeetan.

Mutazioei dagokienez, sailkapen histologikoetan gertatzen zen bezala, aminoazido-aldaketak edota irakurketaren aldaketa suposatzen zuten base-aldaketak ziren. Pronostikoa ezezaguna izan zen kasu gehienetan. Hala ere, sailkapen histologikoan bezala, $C T N N B 1$ geneak WNT azpitaldean pronostiko ona zuen, eta TP53 eta PTCH1 geneek pronostiko larria SHH azpitaldean. Gainera, SUFU genean gertatutako mutazioek terapiarekiko erresistentzia adierazi zuten.

\section{EZTABAIDA}

Meduloblastoma minbizi heterogeneotzat har daiteke adierazpen klinikoa, ezaugarri molekularrak eta azpitalde bakoitzaren biziraupen-tasa kontuan hartzen baditugu [4]. Gaur egun, meduloblastomaren aurkako tratamendua pazientearen arrisku-mailaren arabera ezartzen da soilik, hau da, aldagai kliniko-patologikoak kontuan izanik (adina, metastasiaren agertzea, erresekzioaren hedadura eta azpitalde histologikoa). Hala ere, tratamenduaren ezarpen hori ez da baliagarria paziente batzuentzat. Batzuek, pronostiko ona izan arren, tratamendu intentsiboak eta toxizitateak pairatzen dituzte. Beste batzuek, ordea, birgaixotze goiztiarrak izaten dituzte, nahiz eta arrisku baxuko kasu bezala sailkatuta egon. Horrez gain, berdin sailkatu diren pazienteek eta, ondorioz, terapia berdina jaso dutenek, erantzun-maila desberdina omen dute [5]. Horrek esan nahi du tratamenduarekiko erantzuna tumoreak berak dituen alterazio molekularren menpekoa ere badela. 
Azken urteotan, ikerketa askok punta-puntako teknologiari esker (adierazpen genetikoen eta metilazioen azterketak) sinadura genetikoak identifikatu dituzte meduloblastomen sailkapen molekularra ahalbidetuz. Izan ere, sinadura genetiko horiek gaur egun OMEk onartu ditu [3]. Gainera, NGSren erabilerarekin, tumorearen garapenean eragina duten mutazio genetiko berriak identifikatu dira [17]. Hala ere, gaur egun informazio asko dago literaturan, batez ere gene berriei dagokionez. Literaturan informazio asko izateak, askotan, zaildu egiten du gaixotasunean benetan eragiten duten geneak zein diren jakitea.

Meduloblastoma pediatriakoan gehien mutatutako geneak identifikatzeko eta horien pronostikoa ezagutzeko helburua izan genuen. Lehenik eta behin, bilaketa sistematikoa burutu zen meduloblastoman eragina zuten mutazio somatikoak bilatzeko. Bilaketa horren bidez, gaixotasunaren pronostikoari buruzko informazioa eman zezaketen gene-markatzaileak hautestea lortu genuen. Etorkizunean, markatzaile horiek meduloblastoma pediatrikoaren terapia pertsonalizatuagoak lortzeko tresnaren diseinuaren oinarria izan daitezke, eta tratamendu eraginkorragoak lortu. Lanak paziente pediatrikoetan jarri zuen arreta, meduloblastoma pediatrikoak helduen meduloblastomarekiko jokabide guztiz desberdina duelako [3].

Berrikuspen bibliografikoaren ondoren, 197 gene identifikatu ziren 62 artikulutan. Horietatik 21 genek mutazioak erakutsi zituzten gutxienez \% 2ko maiztasunarekin: TP53, CTNNB1, AXIN1, FAT1, PTCH1, INI1, TERT, DDX3X, SMARCA4, MLL2, SUFU, PTEN, KMD6A, MSH6, NF2, CHD7, PIK3A, KMT2D, MLL3, NRAS eta SMO. Gene horiek azpitalde molekular zein histologiko desberdinetan ageri ziren, INII eta FATI geneak izan ezik. NF2 eta MSH6 geneak artikulu bakarrean azaldu ziren mutatuta, eta, gainera, paziente bakarra aztertu zen [63]. Beraz, ez lirateke gene hautagaiak izango zuzeneko tratamendurako.

INII eta FATI aztertzen zituzten ikerketetan, meduloblastoma guztiak batera aztertu ziren (sailkapenik gabe) [31], [39], [41]. INI1 geneak SWI/ SNF konplexuan parte hartzen du, eta bere funtzioa ATParen menpeko kromatinaren birmoldatzea da [39]. Bestalde, FAT1 genean gertatutako zenbait mutazio somatikok WNT bidezidorraren aktibazioa eragin dezakete; hortaz, FAT1 $\beta$-kateninara lot daiteke zelulen zenbait jokabide erregulatuz [29]. Hala ere, pazienteen sailkapenean laguntzen ez dutenez eta pronostikoa ezezaguna denez, bi gene horiek ez lirateke egokiak izango zuzeneko tratamendua zehazteko, nahiz eta mutazioak $\% 2$ baino maiztasun altuagoan adierazi. Ikerketa gehiago egin beharko lirateke gene horiek azpitalde histologiko edo molekularrekin erlaziorik duten ikusteko.

Azpimarratzekoa da \% 2 baino maiztasun altuagoko mutazioak zituzten gainontzeko 17 geneak sailkapen histologiko edota molekular desberdinekin asoziatuta azaldu zirela. Ondorioz, gene horiek pazienteak azpitalde 
histologiko edota molekular desberdinetan sailkatzen lagundu dezakete. Adibidez, PTEN eta KDM6A soilik meduloblastoma desmoplasikoetan azaldu ziren.

Lehen aipatu bezala, meduloblastomak molekularki lau talde desberdinetan sailka daitezke: WNT, SHH, 3 taldea eta 4 taldea. WNT azpitaldeak dauka pronostiko onena, pazienteen \% 95eko biziraupenarekin [77]. Oro har, histologikoki klasikoak dira, eta ez dute metastasirik izaten. Azpitalde horretan lortutako emaitzetan ikus daiteke maizago mutatuta azaltzen diren geneak $C T N N B 1, D D X 3 X, S M A R C A 4$ eta $K M T 2 D$ direla $(>\% 20)$. CTNNB1 geneko mutazioak askotan identifikatu izan dira talde horretako alterazio bezala. Kasu gehienetan, mutazioak hirugarren exonean agertzen dira [77]. Sailkapen histologikoari dagokionez, gene horretako mutazioak meduloblastoma klasikoan ageri dira, eta proportzio oso txiki batean anaplasikoan. CTNNB1 genea da PNET5 Europako saiakuntza klinikoan (2017an Espainian zabaldua) erabiltzen den markatzaile genetiko bakarra, pazienteak zuzenean WNT azpitaldean sailkatzeko eta tratamendu leunagoa emateko biziraupena murriztu gabe [78]. Gaur egun, ikerketa hori martxan dago, baina oraindik ez da ondorio sendoetara heldu. WNT azpitaldean sarri mutatuta ageri diren gainerako geneak beste taldeetan agertzen direnez, ez dira talde honetarako identifikagarriak izango. Gainera, horien pronostikoa ezezaguna da oraindik.

SHH bidezidorra gakoa da zerebeloaren ohiko garapenean, non Purkinje neuronek SHH estekatzailea jariatzen baitute. Garapen goiztiarrean zehar, SHH ligandoak mitogenesia bultzatzen du kanpo-geruza pikortsuko ama-zeluletan. SHH seinaleari emandako erantzuna zelulen mintzean zeharreko proteina bik kontrolatzen dute; $\mathrm{PTCHI}$ eta horrekin lotuta dagoen SMO (Smoothened) geneek kodetutako bi proteinek [79]. SHH bidezidorraren aktibazioa aberrantea gerta daiteke bidezidor honetan eragina duten osagai desberdinetan gertatzen diren mutazioen ondorioz. Ikerketa honetan, PTCH1 [49, 67] eta SUFU [68] geneetan azaldu ziren pronostikoaren informazioa duten mutazio somatikoak, SHH bidezidorraren kontrolatzaile negatiboak direnak. TP53 genean ere mutazio somatikoak azaldu ziren pronostiko larriarekin [66]. SUFU meduloblastoma desmoplasikoan soilik azaldu zen mutatuta [59]. TP53 eta PTCH1, aldiz, meduloblastoma desmoplasikoan zein klasikoan [49], [51], [55], [61-62]. Hiru geneen kasuan, pronostikoa larria izan zen. Beraz, interesgarria izango litzateke etorkizunean egingo diren saiakuntza klinikoetan gene horiek kontuan hartzea, tratamenduaren intentsitatea handitzeko hautagai bezala edota bestelako terapiak bilatzeko. SHH azpitaldean mutatutako beste geneak TERT, PIK3A eta PTEN izan ziren, baina ez zuten inolako pronostikorik adierazi [6667], [69], [71], [75]. Talde honetan, interesgarria da adieraztea $S M O$ genea, SHH taldeko kide izan arren, ez dela mutatuta azaldu paziente pediatrikoetan (gene honetan deskribatu da mutazioak meduloblastoma helduetan ger- 
tatzen direla [3]). Izan ere, ez zen mutatuta azaldu SHH azpitaldean; soilik WNT azpitaldean eta maiztasun oso baxuan.

3 taldeko pazienteengan diagnosia egiten denerako, metastasikoak izaten dira. Orokorrean, sailkapen histologikoari dagokionez, anaplasikoak dira, baina klasikoak ere ikusi dira. Biziraupenari dagokionez, talde guztietan larriena da [77]. Hala ere, pronostikoa aldatu egiten da metastasia agertzen den ala ez, eta diagnosiaren adina zein den. Horregatik guztiagatik, interes handikoa zen talde honetako ezaguera molekularra handitzea. Alabaina, talde honetan aurkitu ziren mutazioak beste talde batzuetan deskribatu ziren, eta kasu guztietan beste taldeetan baino maiztasun baxuagoak aurkeztu zituzten. Nahiz eta pronostikoa duen mutazio somatikorik ez zen azaldu, azpitalde honetako ezaugarria da MYCren anplifikazioa. Gainera, pronostiko larriarekin erlazionatuta dago, eta pazienteek tratamendu gogorragoa jaso behar dute [18].

4 taldean ezaguna da biziraupenaren maiztasuna \% 75ekoa dela [77]. Kasu honetan, talde honetarako esklusiboa den genea azaldu zen mutatuta: KDM6A. Nahiz eta maiztasuna oso altua ez izan $(<\% 5)$, gene horretan maiz gertatzen dira delezio homozigotikoak 4 taldean [71]. Beraz, interesgarria izango litzateke taldeak desberdintzeko baliagarria den aztertzea. Bilaketa honetan berresten da talde honetako meduloblastomak, ugarienak izan arren, ezezagunenak direla [77].

Azkenik, esan beharra dago ikerketa honek hainbat muga azaltzen dituela. Alde batetik, zenbait artikulutan informazioa falta izan da. Izan ere, ikerketa askotan, aztertzen ziren pazienteen adinak ez ziren adierazten, edota soilik adin-tartea adierazten zen, eta horrek arazo larria eragin zuen. Artikulu asko (eta informazio nahikoa) baztertu behar izan ziren, zehazki 54 (2. irudia), ezin izan zirelako haurrak eta helduak bereizi. Beste alde batetik, zenbait mutazio identifikatu dira horien balio-pronostikoa jakin gabe.

Lan honetan lortutako datuek berresten dute meduloblastoma pediatrikoen ezagutza eta karakterizazio hobe batek tumorearen sailkapena eta arriskuaren araberako pazienteen estratifikazioa errazten dutela. Hala ere, oso kasu gutxitan (CTNNB1, TP53, PTCH1 eta SUFU) eskaintzen dute mutazioek balio-pronostikoa.

\section{ONDORIOAK}

Bilaketa sistematikoan, 21 genek izan dute gutxienez \% 2ko mutaziomaiztasuna, eta horietatik bost gene (TP53, CTNNB1, PTCH1, SUFU, eta KDM6A) izan litezke erabilgarriak diagnosiaren momentuan NGS bidez analizatzeko. Horrela, meduloblastoma duten pazienteetan tratamendu indibidualak presta litezke pazientearen profil molekularrean oinarrituta, terapiarekiko erantzun hobeak lortuz, eta, horri esker, pronostiko hobeak 
lortuko lirateke. Hala ere, ikertzen jarraitu behar da, gene askoren rola oraindik ez dagoelako argi pronostikoan, edo emaitza batzuk balioztatzeko.

\section{ETORKIZUNEKO IKERKETAK}

Meduloblastomaren ezagutzan zenbat eta gehiago aurreratu, orduan eta minbizi heterogeneoago bilakatzen ari da. Bere jatorriaz gutxi dakigu oraindik, baina bere genesian indibiduoarengan izaten diren DNA aldaketek, tumorearen ezaugarri zelularren eta sistema immunearen bidez, indibiduo bakoitzak tumorearen aurrean duen erantzuteko gaitasuna eragiten dute. Jatorriaz gain, gaixotasunari buruzko jakintzak beste fronte berri asko ditu; hala nola, epigenetikak, tumorearen mikroinguruneak eta immunitateak zer-nolako eragina duten tumorean, pazienteen tratamenduarekiko erantzunean eta biziraupenean. Hortaz, oso garrantzitsua da meduloblastomaren genetikaren ezagutzan murgiltzea.

\section{BIBLIOGRAFIA}

[1] PERIS-BONET, R., MARTÍNEZ-GARCIA, C., LACOUR, B., PETROVICH, S., GINER-RIPOLL, B., NAVAJAS, A. eta STELIAROVA-FOUCHER, E. 2006. «Childhood central nervous system tumours incidence and survival in Europe (1978-1997): report from Automated Childhood Cancer Information System project». European Journal of Cancer, 42, 2064-2080.

[2] PERIS BONET, R., PARDO ROMAGUER, A.E. eta MUÑOS LÓPEZ, A. 2017. «Cáncer Infantil en España. Estadística 1980-2016. Registro Español de Tumores Infantiles (RETI-SEHOP)». Valentzia: Universitat de València.

[3] LOUIS, D.N., PERRY, A., REIFERENBERGER, G., VON DEIMLING, A., FIGARELLA-BRANGER, D., CAVENEE, W.K., et al. 2016. «The 2016 World Health Organization Classification of Tumors of the Central Nervous System: a summary». Acta Neuropathologica, 131, 803-820.

[4] NORTHCOTT, P.A., KORSHUNOV, A., WITT, H., HIELSCHER, T., EBERHART, C.G., MACK, S., et al. 2011. «Medulloblastoma comprises four distinct molecular variants». Journal of Clinical Oncology, 29, 1408-1414.

[5] GILBERTSON, R.J. 2004. «Medulloblastoma: signaling a change in treatment». The Lancet Oncology, 5, 209-218.

[6] RIS, M.D., PACKER, R., GOLDWEIN, J., JONES-WALLACE, D. eta BOYETT, J.M. 2001. «Intellectual outcome after reduced-dose radiation therapy plus adjuvant chemotherapy for medulloblastoma: a Children's Cancer Group study». Journal of Clinical Oncology, 19, 3470-3476.

[7] TAYLOR, M.D., NORTHCOTT, P.A., KORSHUNOV, A., REMKE, M., CHO, Y.J., CLIFFORD, S.C., et al. 2012. «Molecular subgroups of medulloblastoma: the current consensus». Acta Neuropathologica, 123, 465-472. 
[8] KOOL, M., KORSHUNOV, A., REMKE, M., JONES, D.T., SCHLANSTEIN, M., NORTHCOTT, P.A., et al. 2012. «Molecular subgroups of medulloblastoma: an international meta-analysis of transcriptome, genetic aberrations, and clinical data of WNT, SHH, Group 3, and Group 4 medulloblastomas». Acta Neuropathologica, 123, 473-484.

[9] CHO, Y.J., TSHERNIAK, A., SANTAGATA, S., LIGON, A., GREULICH, H., BERHOUKIM, R., et al. 2011. «Integrative genomic analysis of medulloblastoma identifies a molecular subgroup that drives poor clinical outcome». Journal of Clinical Oncology, 29, 1424-1430.

[10] SCHWALBE, E.C., WILLIAMSON, D., LINDSEY, J.C., HAMILTON, D., RYAN, S. L., MEGAHED, H., et al. 2013. «DNA methylation profiling of medulloblastoma allows robust subclassification and improved outcome prediction using formalin-fixed biopsies». Acta Neuropathologica, 125, 359371.

[11] HOVESTADT, V., REMKE, M., KOOL, M., PIETSCH, T., NORTHCOTT, P.A., FISCHER, R., et al. 2013. «Robust molecular subgrouping and copynumber profiling of medulloblastoma from small amounts of archival tumour material using high-density DNA methylation arrays». Acta Neuropathologica, 125, 913-916.

[12] PIETSCH, T., SCHMIDT, R., REMKE, M., KORSHUNOV, A., HOVESTADT, V., JONES, D.T., et al. 2014. «Prognostic significance of clinical, histopathological, and molecular characteristics of medulloblastomas in the prospective HIT2000 multicenter clinical trial cohort». Acta Neuropathologica, 128, 137-149.

[13] MORIN, P.J. 1999. «Beta-catenin signaling and cancer». Bioessays, 21, 1021-1030.

[14] CLEVERS, H. 2000. «Axin and hepatocellular carcinomas». Nature Genetics, 24, 206-208.

[15] TAIPALE, J. eta BEACHY, P.A. 2001. «The Hedgehog and Wnt signalling pathways in cancer». Nature, 411, 349-354.

[16] SCHWALBE, E.C., LINDSEY, J.C., NAKJANG, S., CROSIER, S., SMITH, A.J., HIKS, D., et al. 2017. «Novel molecular subgroups for clinical classification and outcome prediction in childhood medulloblastoma: a cohort study». The Lancet Oncology, 18, 958-971.

[17] JONES, D.T., JÄGER, N., KOOL, M., ZICHNER, T., HUTTER, B., SULTAN, M., et al. 2012. «Dissecting the genomic complexity underlying medulloblastoma». Nature, 488, 100-105.

[18] NORTHCOTT, P.A., JONES, D.T., KOOL, M., ROBINSON, G.W., GILBERTSON, R.J., CHO, Y.J., et al. 2012. «Medulloblastomics: the end of the beginning». Nature Reviews Cancer, 12, 818-834.

[19] KARAJANNIS, M.A. eta ZAGZAG, D. 2015. Molecular pathology of nervous system tumors. Biological stratification and targeted therapies. Springer, New-York. 
[20] SIRAVEGNA, G., MARSONI, S., SIENA, S. eta BARDELLI, A. 2017. «Integrating liquid biopsies into the management of cancer». Nature Reviews Cancer, 14, 531-548.

[21] CONNOLLY, I.D., LI, Y., GEPHART, M.H. eta NAGPAL, S. 2016. «The "Liquid Biopsy": The Role of Circulating DNA and RNA in Central Nervous System Tumors». Current Neurology and Neuroscience Reports, 16, 25.

[22] DE MATTOS-ARRUDA, L., MAYOR, R., NG, C.K.Y., WEIGELT, B., MARTÍNEZ-RICARTE, F., TORREJON, D., et al. 2015. «Cerebrospinal fluid-derived circulating tumour DNA better represents the genomic alterations of brain tumours than plasma». Nature Communications, 6, 8839 .

[23] SKOG, J., WÜRDINGER, T., VAN RIJN, S., MEIJER, D.H., GAINCHE, L., SENA-ESTEVES, M., et al. 2008. «Glioblastoma microvesicles transport RNA and protein that promote tumor growth and provide diagnostic biomarkers». Nature Cell Biology, 10, 1470-1476.

[24] D'ASTI, E., GARNIER, D., LEE, T.H., MONTERMINI, L., MEEHAN, B. eta RAK, J. 2012. «Oncogenic extracellular vesicles in brain tumor progression». Frontiers in physiology, 3, 294.

[25] MACARTHUR, K.M., KAO, G.D., CHANDRASEKARAN, S., ALONSOBASANTA, M., CHAPMAN, C., LUSTIG, R.A., et al. 2014. «Detection of brain tumor cells in the peripheral blood by a telomerase promoter-based assay». Cancer Research. 74, 2152-2159.

[26] ZACHARIAH, M.A., OLIVEIRA-COSTA, J.P., CARTER, B.S., STOTT, S.L. eta NAHED, B.V. 2018. «Blood-Based Biomarkers for the Diagnosis and Monitoring of Gliomas». Neuro-Oncology, 20, 1155-1161.

[27] COEBERGH VAN DEN BRAAK, R.R.J., SIEUWERTS, A.M., LALMAHOMED, Z.S., SMID, M., WILTING, S.M., BRIL, S.I., et al. 2018. «Confirmation of a metastasis-specific microRNA signature in primary colon cancer». Scientific Reports, 8, 5242.

[28] HIRONAKA-MITSUHASHI, A., MATSUZAKI, J., TAKAHASHI, R.U., YOSHIDA, M., NEZU, Y., YAMAMOTO, Y., et al. 2017. «A tissue microRNA signature that predicts the prognosis of breast cancer in young women». PLoS One, 12, e0187638.

[29] TANTAWY, M., ELZAYAT, M.G., YEHIA, D. eta TAHA, H. 2018. «Identification of microRNA signature in different pediatric brain tumors». Genetics and Molecular Biology, 41, 27-34.

[30] BALLESTER, L.Y., FULLER, G.N., POWELL, S.Z., SULMAN, E.P., PATEL, K.P., LUTHRA, R., eta ROUTBORT, M.J. 2017. «Retrospective analysis of molecular and immunohistochemical characterization of 381 primary brain tumors». Journal of Neuropathology \& Experimental Neurology, 76, 179-188.

[31] YU, J. eta LI, H. 2017. «The expression of FAT1 is associated with overall survival in children with medulloblastoma». Tumor Journal, 103, 44-52. 
[32] WANG, Y., SPRINGER, S., ZHANG, M., MCMAHON, K.W., KINDE, I., DOBBYN, L., et al. 2015. «Detection of tumor-derived DNA in cerebrospinal fluid of patients with primary tumours of the brain and spinal cord». $\mathrm{Na}$ tional Academy of Sciences of the United States, 112, 9704-9709.

[33] HUANG, D.S., WANG, Z., HE, X.J., DIPLAS, B.H., YANG, R., KILLELA, P.J., et al. 2015. «Recurrent TERT promoter mutations identified in a large-scale study of multiple tumour types are associated with increased TERT expression and telomerase activation». European Journal of Cancer, 51, 969-976.

[34] TABORI, U., BASKIN, B., SHAGO, M., ALON, N., TAYLOR, M.D., RAY, P.N., et al. 2010. «Universal poor survival in children with medulloblastoma harboring somatic TP53 mutations». Journal of Clinical Oncology, 28, 1345-1350.

[35] GIANGASPERO, F., WELLEK, S., MASUOKA, J., GESSI, M., KLEIHUES, P. eta OHGAKI, H. 2006. «Stratification of medulloblastoma on the basis of histopathological grading». Acta Neuropathologica, 112, 5-12.

[36] ELLISON, D.W., ONILUDE, O.E., LINDSEY, J.C., LUSHER, M.E., WESTON, C.L., TAYLOR, R.E., et al. 2005. « $\beta$-Catenin status predicts a favorable outcome in childhood medulloblastoma: the United Kingdom Children's Cancer Study Group Brain Tumour Committee». Journal of Clinical Onco$\log y, 23,7951-7957$.

[37] BAEZA, N., MASUOKA, J., KLEIHUES, P. eta OHGAKI, H. 2003. «AXIN1 mutations but not deletions in cerebellar medulloblastomas». Oncogene, 30, 632-636.

[38] ZAGZAG, D., MILLER, D.C., KNOOP, E., FARMER, J.P., LEE, M., BIRIA, S., et al. 2000. «Primitive neuroectodermal tumors of the brainstem: investigation of seven cases». Pediatrics, 106, 1045-1053.

[39] BIEGEL, J.A., FOGELGREN, B., ZHOU, J.Y., JAMES, C.D., JANSS, A.J., ALEEN, J.C., et al. 2000. «Mutations of the INI1 rhabdoid tumor suppressor gene in medulloblastomas and primitive neuroectodermal tumors of the central nervous system». Clinical Cancer Research, 6, 2759-2763.

[40] HUANG, H., MAHLER-ARAUJO, B.M., SANKILA, A., CHIMELLI, L., YONEKAWA, Y., KLEIHUES, P. eta OHGAKI, H. 2000. «APC mutations in sporadic medulloblastomas». The American Journal of Pathology, 156, 433-437.

[41] SÉVENET, N., LELLOUCH-TUBIANA, A., SCHOFIELD, D., HOANGXUAN, K., GESSLER, M., BIRNBAUM, D., et al. 1999. «Spectrum of hSNF5/INI1 somatic mutations in human cancer and genotype-phenotype correlations». Human Molecular Genetics, 8, 2359-2368.

[42] VORECHVSKÝ, I., TINGBY, O., HARTMAN, M., STRÖMBERG, B., NISTER, M., COLLINS, V.P. eta TOFTGARD, R. 1997. «Somatic mutations in the human homologue of Drosophila patched in primitive neuroectodermal tumours». Oncogene, 15, 361-366.

[43] TSUMANUMA, I., TANAKA, R., ABE, S., KAWASAKI, T., WASHIYAMA, K. eta KUMANISHI, T. 1997. «Infrequent mutation of Waf1/p21 
gene, a CDK inhibitor gene, in brain tumors». Neurologia Medico-Vhirurgica, 37, 150-157.

[44] PHERLAN, C.M., LiU, L., RUTTledGE, M.H., MUNTZNinG, K., RIDDERHEIM, P.A. eta COLLINS, V.P. 1995. «Chromosome 17 abnormalities and lack of TP53 mutations in paediatric central nervous system tumours». Human Genetics, 96, 684-690.

[45] SAYLORS, R.L., SIDRANSKY, D., FRIEDMAN, H.S., BIGNER, D.D., VOGELSTEIN, B. eta BRODEUR, G.M. 1991. «Infrequent p53 gene mutations in medulloblastomas». Cancer Research, 51, 4721-4723.

[46] COGEN, P.H., DANESHVAR, L., METZGER, A.K., DUYK, G., EDWARDS, M.S. eta SHEFFIELD, V.C. 1992. «Involvement of multiple chromosome $17 \mathrm{p}$ loci in medulloblastoma tumorigenesis». American Journal of Human Genetics, 50, 584-589.

[47] TABUCHI, K., FUKUYAMA, K., MINETA, T., OH-UCHIDA, M. R. eta HORI, K. 1992. «Altered structure and expression of the p53 gene in human neuroepithelial tumors». Neurologia Medico-Chirurgica (Tokyo), 32, 725-732.

[48] GORSI, H.S., MALICKI, D.M., BARSAN, V., TUMBLIN, M., YEH-NAYRE, L., MILBURN, M., et al. 2019. «Nivolumab in the treatment of recurrent or refractory pediatric brain tumors: a single institutional experience». Journal of Pediatric Hematology/Oncology, 41, e235-e241.

[49] KLINE, C.N., JOSEPH, N.M., GRENERT, J.P., VAN ZIFFLE, J., TALEVICH, E., ONODERA, C., et al. 2016. «Targeted next-generation sequencing of pediatric neuro-oncology patients improves diagnosis, identifies pathogenic germline mutations, and directs targeted therapy». Neuro-Oncology, 19, 699-709.

[50] VIANA-PEREIRA, M., ALMEIDA, G.C., STAVALE, J.N., MALHEIRO, S., CLARA, C., LOBO, P., et al. 2017. «Study of hTERT and histone 3 mutations in medulloblastoma». Pathobiology, 84, 108-113.

[51] PARSONS, D.W., LI, M., ZHANG, X., JONES, S., LEARY, R.J., LIN, J.C.H., et al. 2011. «The genetic landscape of the childhood cancer medulloblastoma». Science, 331, 435-439.

[52] ELLISON, D.W., KOCAK, M., DALTON, J., MEGAHED, H., LUSHER, M.E., RYAN, S.L., et al. 2011. «Definition of disease-risk stratification groups in childhood medulloblastoma using combined clinical, pathologic, and molecular variables». Journal of Clinical Oncology, 29, 1400-1407.

[53] FATTET, S., HABERLER, C., LEGOIX, P., VARLET, P., LELLOUCHTUBIANA, A., LAIR, S., et al. 2009. «Beta-catenin status in paediatric medulloblastomas: correlation of immunohistochemical expression with mutational status, genetic profiles, and clinical characteristics». The Journal of Pathology: A Journal of the Pathological Society of Great Britain and Ireland, 218, 86-94.

[54] VIANA-PEREIRA, M., ALMEIDA, I., SOUSA, S., MAHLER-ARAÚJO, B., SERUCA, R., PIMENTEL, J. eta REIS, R.M. 2009. «Analysis of microsatellite instability in medulloblastoma». Neuro-Oncology, 11, 458-467. 
[55] HUANG, J., GROTZER, M.A., WATANABE, T., HEWER, E., PIETSCH, T., RUTKOWSKI, S. eta OHGAKI, H. 2008. «Mutations in the Nijmegen breakage syndrome gene in medulloblastomas». Clinical Cancer Research, 14, 4053-4058.

[56] CLIFFORD, S.C., LUSHER, M.E., LINDSEY, J.C., LANGDON, J.A., GILBERTSON, R. J., STRAUGHTON, D. eta ELLISON, D.W. 2006. «Wnt/ wingless pathway activation and chromosome 6 loss characterise a distinct molecular sub-group of medulloblastomas associated with a favourable prognosis». Cell Cycle, 5, 2666-2670.

[57] MISAKI, K., MARUKAWA, K., HAYASHI, Y., FUKUSATO, T., MINAMOTO, T., HASEGAWA, M., et al. 2005. «Correlation of $\gamma$-catenin expression with good prognosis in medulloblastomas». Journal of Neurosurgery, 102, 197-206.

[58] YOKOTA, N., NISHIZAWA, S., OHTA, S., DATE, H., SUGIMURA, H., NAMBA, H. eta MAEKAWA, M. 2002. «Role of Wnt pathway in medulloblastoma oncogenesis». International Journal of Cancer, 101, 198-201.

[59] TAYLOR, M.D., LIU, L., RAFFEL, C., HUI, C.C., MAINPRIZE, T.G., ZHANG, X., et al. 2002. «Mutations in SUFU predispose to medulloblastoma». Nature Genetics, 31, 306-310.

[60] EBERHART, C.G., TIHAN, T. eta BURGER, P.C. 2000. «Nuclear localization and mutation of beta-catenin in medulloblastomas». Jorunal of Neuropathology \& Experimental Neurology, 59, 333-337.

[61] WOLTER, M., REIFENBERGER, J., SOMMER, C., RUZICKA, T. eta REIFENBERGER, G. 1997. «Mutations in the human homologue of the Drosophila segment polarity gene patched (PTCH) in sporadic basal cell carcinomas of the skin and primitive neuroectodermal tumors of the central nervous system». Cancer Research, 57, 2581-2585.

[62] XIE, J., JOHNSON, R.L., ZHANG, X., BARE, J.W., WALDMAN, F.M., COGEN, P.H., et al. 1997. «Mutations of the PATCHED gene in several types of sporadic extracutaneous tumors». Cancer Research, 57, 23692372.

[63] LINDSAY, H., SCOLLON, S., REUTHER, J., VOICU, H., REDNAM, S.P., LIN, F.Y., et al. 2019. «Germline POLE mutation in a child with hypermutated medulloblastoma and features of constitutional mismatch repair deficiency». Molecular Case Studies, 5, a004499.

[64] KORSHUNOV, A., SAHM, F., ZHELUDKOVA, O., GOLANOV, A., STICHEL, D., SCHRIMPF, D., et al. 2018. «DNA methylation profiling is a method of choice for molecular verification of pediatric WNT-activated medulloblastomas». Neuro-Oncology, 21, 214-221.

[65] PETRIRENA, G.J., MASLIAH-PLANCHON, J., SALA, Q., POURROY, B., FRAPPAZ, D., TABOURET, E., et al. 2018. «Recurrent extraneural sonic hedgehog medulloblastoma exhibiting sustained response to vismodegib and temozolomide monotherapies and inter-metastatic molecular hetelogeneity at progession». Oncotarget, 9, 10175-10183. 
[66] SCHWALBE, E.C., LINDSEY, J.C., NAKJANG, S., CROSIER, S., SMITH, A.J., HICKS, D., et al. 2017. «Novel molecular subgroups for clinical classification and outcome prediction in childhood medulloblastoma: a cohort study». The Lancet Oncology, 18, 958-971.

[67] RAMKISSOON, S.H., BANDOPADHAYAY, P., HWANG, J., RAMKISSOON, L.A., GREENWALD, N.F., SCHUMACHER, S.E., et al. 2017. «Clinical targeted exome-based sequencing in combination with genomewide copy number profiling: precision medicine analysis of 203 pediatric brain tumors». Neuro-Oncology, 19, 986-996.

[68] KOOL, M., JONES, D.T., JÄGER, N., NORTHCOTT, P.A., PUGH, T.J., HOVESTADT, V., et al. 2014. «Genome sequencing of SHH medulloblastoma predicts genotype-related response to smoothened inhibition». Cancer Cell, 25, 393-405.

[69] LiNDSEY, J.C., SCHWALBE, E.C., POTLURI, S., BAILEY, S., WILLIAMSON, D. eta CLIFFORD, S.C. 2014. «TERT promoter mutation and aberrant hypermethylation are associated with elevated expression in medulloblastoma and characterise the majority of non-infant SHH subgroup tumours». Acta Neuropathologica, 127, 307-309.

[70] JONES, D.T., JÄGER, N., KOOL, M., ZICHNER, T., HUTTER, B., SULTAN, M., et al. 2012. «Dissecting the genomic complexity underlying medulloblastoma». Nature, 488, 100-105.

[71] PUGH, T.J., WEERARATNE, S.D., ARCHER, T.C., KRUMMEL, D.A.P., AUCLAIR, D., BOCHICCHIO, J., et al. 2012. «Medulloblastoma exome sequencing uncovers subtype-specific somatic mutations». Nature, 488, 106110.

[72] ROBINSON, G., PARKER, M., KRANENBURG, T.A., LU, C., CHEN, X., DING, L., et al. 2012. «Novel mutations target distinct subgroups of medulloblastoma». Nature, 488, 43-48.

[73] SCHWALBE, E.C., LINDSEY, J.C., STRAUGHTON, D., HOGG, T.L., COLE, M., MEGAHED, H., et al. 2011. «Rapid diagnosis of medulloblastoma molecular subgroups». Clinical Cancer Research, 17, 1883-1894.

[74] SHUANGSHOTI, S., TADADONTIP, P., TECHAVICHIT, P., THORNER, P.S., SHUANGSHOTI, S. eta TEERAPAKPINYO, C. 2020. «Simplified Molecular Subtyping of Medulloblastoma for Reduced Cost and Improved Turnaround Time». Applied Immunohistochemistry \& Molecular Morphology, 28, 538-543.

[75] MINASI, S., BALDI, C., PIETSCH, T., DONOFRIO, V., POLLO, B., ANTONELLI, M., et al. 2019. «Telomere elongation via alternative lengthening of telomeres (ALT) and telomerase activation in primary metastatic medulloblastoma of childhood». Journal of Neuro-Oncology, 142, 435-444.

[76] PHI, J.H., PARK, A.K., LEE, S., CHOI, S.A., BAEK, I.P., KIM, P., et al. 2018. «Genomic analysis reveals secondary glioblastoma after radiotherapy in a subset of recurrent medulloblastomas». Acta Neuropathologica, 135, 939-953. 
Begoña Frutos-Gallastegui, Elixabet López-López, Unai Illarregi, Nerea Bilbao-Aldaiturriaga, Miguel García-Ariza, Ángela Gutiérrez-Camino, Idoia Martín-Guerrero

[77] SKOWRON, P., RAMASWAMY, V. eta TAYLOR, M.D. 2015. «Genetic and molecular alterations across medulloblastoma subgroups». Journal of Molecular Medicine (Berlin, Germany), 93, 1075-1084.

[78] ClinicalTrials.gov [Internet]. Bethesda (MD): National Library of Medicine (US). Identifier NCT02066220, International Society of Paediatric Oncology (SIOP) PNET 5 Medulloblastoma. https://clinicaltrials.gov/ct2/show/ NCT02066220

[79] CLIFFORD, S.C., LANNERING, B., SCHWALBE, E.C., HICKS, D., O’TOOLE, K., NICHOLSON, S.L., et al. 2015. «Biomarker-driven stratification of disease-risk in non-metastatic medulloblastoma: Results from the multicenter HIT-SIOP-PNET4 clinical trial». Oncotarget, 6, 38827-38839. 